\title{
Environmental Impact Assessment Studies of Ground Water in Solapur Thermal Power Plant Area (Maharashtra), India
}

\author{
${ }^{1}$ M. P. Joshi, ${ }^{2}$ P. V. Barde, ${ }^{3}$ P. V. Mungantiwar, ${ }^{4}$ A. V. Bhole $\&{ }^{5}$ V. D. Devarkar \\ 1,2,3,4 Surya Envirotech, Hanuman Nagar, Nagpur Pin-440009 (MS, INDIA) \\ 1,2Department of Botany, SCS College, Omerga Dist. Osmanabad Pin-413606 (MS, INDIA) \\ Corresponding Author: devarkar28@gmail.com
}

\section{Manuscript Details}

Manuscript Submitted : 12/08/2019

Manuscript Revised : 15/09/2019

Manuscript Accepted : 10/11/2019

Manuscript Published : 15/11/2019

\section{Available On}

https://plantaescientia.website/ojs

\section{Cite This Article As}

Joshi M P, Barde P V, Mungantiwar P V, Bhole A V, \& Devarkar V D (2019) Environmental Impact Studies of Ground Water in Solapur Thermal Power Plant Area (Maharashtra), India, Pla. Sci. 2019; Vol. 02 Iss. 04: 48-52. DOI: https://doi.org/10.32439/ps.v2i4.48-52

\section{Copyright}

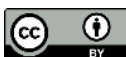

(C) The Author (s). 2018. Open Access This article is distributed under the terms of the Creative Commons Attribution 4.0 International License http://creativecommons.org/licenses/by/4.0/

\section{$\underline{\text { Indexed In }}$}

Crossref, Index Copernicus International (ICI), Directory of Research Journal Indexing (DRJI), Scientific Indexing Services (SIS),

\section{CiteFactor,}

\section{ABSTRACT}

Groundwater is a major source of drinking water in both urban and rural areas of Solapur. Solapur city is growing rapidly in terms of population, changing lifestyle and intense competition among users-agriculture, industry and domestic sectors is driving the groundwater to fall. Besides, discharge of untreated wastewater through bores and leachate from unscientific disposal of solid wastes also contaminate groundwater, thereby reducing quality of fresh water resources. In the work of Solapur, water samples were collected from around the villages in thermal power plant and water quality assessment was carried out from April $2015 \&$ November 2015.The surface and ground water characteristics have been established through analysis of water samples collected during the study area with respect to physico-chemical characteristics and pollutant levels and the same has been compared with quality criteria for drinking water (IS: 10500). From the study it is observed that the samples collected at all the ll locations during pre-monsoon season are well within the prescribed limits laid by IS10500. We obtained less values in Post Monsoon are compared to Pre Monsoon season because of scanty rainfall.

Keywords: Environmental Impact Assessment, Physicochemical Characteristics, Ground Water studies, Solapur Thermal Power Plant 


\section{INTRODUCTION}

Water is an absolute necessity if life must be sustained on earth. In the last few decades, the use of water has diversified in different spectrum. Hence there has been a tremendous increase in the demand for fresh water due to rapid growth of population and the accelerated pace of industrialization. Therefore, the importance of natural water bodies does not need elaborate emphasis; this is because, whatever that affects water bodies has direct or indirect effect on human health. Naturally, water is second only to air among the most important resources for human existence; however, it is the most threatened of the two. Rapid urbanization due to industrialization, especially in developing countries like India, has affected the availability and quality of groundwater due to its overexploitation and improper waste disposal, in urban areas. The impact of village toxic and hazardous wastes on aquatic life including microorganisms has recently received alarming concern globally (Obire et al., 2008).

The human race is under tremendous threat due to undesired changes in the physical, chemical and biological characteristics of air, water and soil. Due to increased human population, industrialization, use of fertilizers and manmade activities, water is highly polluted with different harmful contaminants (Patil et al., 2012). According to WHO, about $80 \%$ of all the diseases in human beings are caused due to water. Pathogens can produce waterborne diseases in either human or animal hosts. Alteration of water's physical chemistry includes acidity (change in $\mathrm{pH}$ ), electrical conductivity, temperature, and eutrophication (Tiwari and Goel, 1986). Depending on the degree of eutrophication, subsequent negative environmental effects such as anoxia (oxygen depletion) and severe reductions in water quality may occur, affecting fish and other animal populations (Aruna Sharma and Khan).

\section{STUDY AREA}

Solapur is lying in the heart of the dry zone. Solapur is located in the assured rainfall zone with temperature ranging from $21^{\circ} \mathrm{C}$ to $41^{\circ} \mathrm{C}$. The soil is black to red vertisol, entisol and inceptisol with $\mathrm{pH}$ ranging from 7-7.5. The rainfall ranges from $700 \mathrm{~mm}$ to $900 \mathrm{~mm}$ with $75 \%$ dependability.Solapur experiences a tropical monsoon type of climate. The southwest monsoon lasts from June to September. The winter season lasts from December to February and the summer extends from March to May. December is the coldest month with the mean diurnal temperature varies between $15^{\circ} \mathrm{C}$ and $30^{\circ} \mathrm{C}$. May is the hottest month with the mean diurnal temperature varying between $24^{\circ} \mathrm{C}$ and $38^{\circ} \mathrm{C}$. The air is humid during monsoon months; relative humidity ranges between 45 and $89 \%$ in the morning and $17-70 \%$ in the evening. The wind speed varies between $7.9 \mathrm{kmph}$ in December and $11.3 \mathrm{kmph}$ in June averaging 9.1kmph annually. (Fig. 1: Index Map).

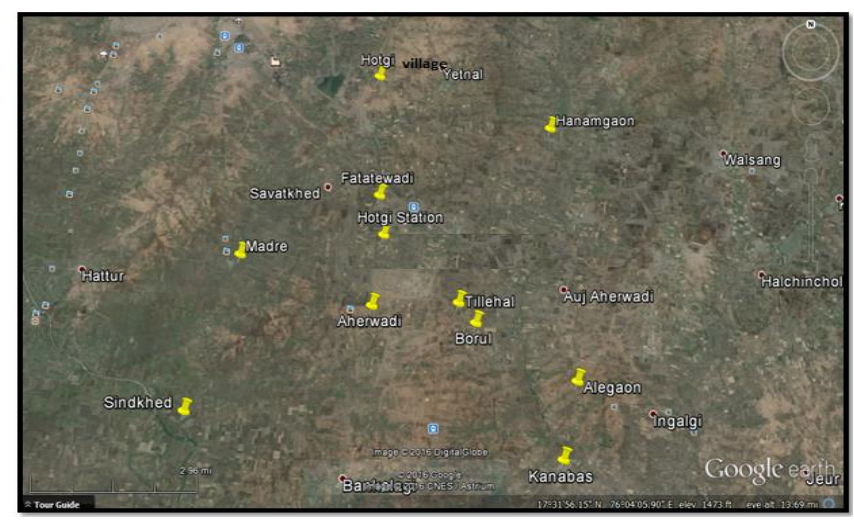

Figure 1: Study Area Map

The average annual rainfall in the region is about $739.18 \mathrm{~mm}$. However, the same for South Solapur taluka for last 15 years is found to be $542.2 \mathrm{~mm}$. Rainfall peaks during July (about $158.14 \mathrm{~mm}$ ) followed by October (about $139.58 \mathrm{~mm}$ ) with the four monsoon months (June to October) contributing 87\% of the total rainfall. The rainfall in the district varies from $448.8 \mathrm{~mm}$. (17.67") at Akluj near the western border to 689.2 mm. (27.14") at Akkalkot near the south-eastern border of the district. Non seasonal rain in the form of thunderstorm occurs during the months of April and May. The rainfall during the south-west monsoon in the months of June to September amounts to about 87 per cent of the annual rainfall. October is the wettest month. About $19 \%$ of the normal annual rainfall in the district is received in the postmonsoon month of October.

\section{MATERIALS AND METHODS}

Total 11 ground water samples were collected either from dug well or bore well at different villages of South Solapur taluka of Solapur district. The sampling was done in the month of April, 2015 (Pre monsoon) \& November 2015 (Post monsoon). By the time that a samples were collected in the field and transported for analysis in the laboratory, some physical change and chemical/ biochemical reactions, may take place in the sample container which would change the intrinsic quality of the sample. Samples collected for the laboratory analysis to know physico-chemical characteristics of water quality were analyzed. The mode of sample preservation and method of analysis is depicted in Table 1 .

\section{RESULTS AND DISCUSSION}

The ground water sample analysis of South Solapur taluka of Solapur district was carried out from the month of April, 2015 (Pre monsoon) (Table 2) \& November 2015 (Post 
monsoon) (Table 3) for the predefined eleven sampling location.

The values of Total Dissolved Solids (TDS) was highest at Madre i.e. $2841 \mathrm{mg} / \mathrm{lit}$ and lowest at Aherwadi i.e. $252 \mathrm{mg} / \mathrm{lit}$ for pre-monsoon season whereas during Post Monsoon Season the TDS observed is highest at Aherwadi and Sindhkhed i.e. $1560 \mathrm{mg} /$ lit and lowest detected at Madre i.e. $402 \mathrm{mg} / \mathrm{lit}$.

The TDS observed in the study area resulted highest at Madre for pre Monsoon Season. In post monsoon season the less value of TDS was low as compared to Pre Monsoon season because of scanty rainfall. There was no addition of suspended particles to get dissolved in the water due to heavy or moderate rainfall as it happens usually after rainy season.

The $\mathrm{pH}$ was alkaline at 08 locations whereas acidic at 03 locations in Post Monsoon Season but all were within the prescribed limits laid by the IS10500. The highest alkaline $\mathrm{pH}$ value was obtained at Tillehal i.e. 7.85 while lowest at Fatatewadi is 6.92. In pre monsoon season all the 11 samples from the sampling locations were in alkaline in nature. The highest $\mathrm{pH}$ value was 7.9 at Alegaon and lowest at Madre 7.02 .

The comparison study tells us that the ground water in the study area becomes acidic in Post Monsoon Season. It may be concluded that the nitrogen getting fixed from fertilizers resulted in formation of nitric or nitrous acid in the soil and ground water hence the ground water turning acidic.

The values of Nitrates as $\left(\mathrm{NO}_{3}\right)$ was monitored and the highest value obtained was at Kanabas i.e. $4.26 \mathrm{mg} / \mathrm{lit}$. Whereas lowest at Borwl i.e. $0.33 \mathrm{mg} / \mathrm{lit}$.in premonsoon season. The highest value obtained at Hotgi station is 11.8 $\mathrm{mg} /$ lit and lowest at Aherwadi is $1.21 \mathrm{mg}$ /lit during post monsoon season.

The Comparison study tells us that the concentration of Nitrate in ground water in the study area increases in Post monsoon Season. The cause of this problem could be pointed towards the excess use of fertilizers by local farmers.

The values of Chemical Oxygen Demand (COD) were highest at Hotgi Station i.e. $43.15 \mathrm{mg} /$ lit and lowest detected at Borwl i.e. $10 \mathrm{mg} / \mathrm{lit}$. And during Post Monsoon Season COD was highest at Sindkhad i.e. $56.0 \mathrm{mg}$ /lit and lowest detected at Fatatewadi, Madre and Hanamgaon i.e. less than $01 \mathrm{mg} / \mathrm{lit}$.

The average value of COD in Post Monsoon season in the study area was less than the Pre Monsoon season. Due to scanty rainfall there was no drain-out and dissolution of chemicals were present in the soil.
The highest value of Ammonia at Tillehal, Hotgi village and Hotgi station was $1.96 \mathrm{mg} / \mathrm{lit}$ and lowest value was at Borwl i.e. $<0.1 \mathrm{mg} / \mathrm{lit}$. In the Post Monsoon Season the highest value was at Fatatewadi $1.12 \mathrm{mg} /$ lit and lowest value at Borwl i.e. $0.1 \mathrm{mg} / \mathrm{lit}$.

The concentration of Ammonia in the ground water is higher in all most all the locations in the study area for Post Monsoon Season than the Pre Monsoon Season.

The values of Total Suspended Solids (TSS) were highest at Aherwadi i.e. $13 \mathrm{mg} /$ lit and lowest detected at Shindhkhed, Madre, Kanabas, Borwl, Alegaon, Tillehal and Hotgivillage i.e. $10 \mathrm{mg} /$ /it. And during Post Monsoon Season TSS was highest at Hotgi station i.e. $23 \mathrm{mg} /$ lit and lowest detected at Borwl i.e. $13 \mathrm{mg} /$ lit. The higher value of TSS in Post Monsoon Season than Pre Monsoon Season can be pointed at the dry air which carried suspended particles getting mixed with water.

The highest value of Dissolved Phosphate was at Madre and Fatatewadi is $1.56 \mathrm{mg} /$ lit and lowest value at Borwl, Alegaon and Tillehal i.e. $0.01 \mathrm{mg} / \mathrm{lit}$. In the Post Monsoon Season whereas the highest value at Hotgi is $1.08 \mathrm{mg} /$ lit. And lowest value was at Fatatewadi, Kanabas, Borwl, Alegaon, Tillehal, Hanamgaon and Hotgi station i.e. $0.01 \mathrm{mg} / \mathrm{lit}$. in Pre Monsoon Season.

The concentration of Dissolve Phosphate in the ground water was higher in all most all the locations in the study area for Post Monsoon Season than the Pre monsoon Season. The reason behind this can be pointed towards the excess use of fertilizers by farmers.

The values of Dissolved Oxygen (DO) were highest at Madre i.e. $6.8 \mathrm{mg} / \mathrm{lit}$ and lowest detected at Sindhkhad i.e. 4.2 $\mathrm{mg} /$ lit. And during Post Monsoon Season DO is highest at Sindhkhed and Kanabas i.e. $4.0 \mathrm{mg} / \mathrm{lit}$ and lowest detected at Alegaon i.e. $3.6 \mathrm{mg} /$ lit.

The average value of DO in Post Monsoon season in the study area was less than the Pre Monsoon season. Due to Scanty rainfall the ground water level was low in Post Monsoon Season than in Pre Monsoon Season.

The value of Bio-Chemical Oxygen Demand (BOD) was less than 10 at 05 locations out of 11 sampling locations. BOD of Hotgi station was $14.3 \mathrm{mg} / \mathrm{lit}$, at Ahirwadi is $10.0 \mathrm{mg} / \mathrm{lit}$ and at Fatatewadi is $13.0 \mathrm{mg} / \mathrm{lit}$ in pre monsoon season. Whereas the BOD values were very less (approximatelmg/lit) in post monsoon season. 
Table: 1: Mode of Sample Preservation and Method of Analysis

\begin{tabular}{|c|c|c|c|c|}
\hline $\begin{array}{l}\text { Sr. } \\
\text { No. }\end{array}$ & Parameters & Container & Preservatives & Name of Method \\
\hline 1 & $\mathrm{pH}$ & BSGB, PEC. & Analyze immediately at $4^{\circ} \mathrm{C}$ & Electrometric Method \\
\hline 2 & TSS & BSGB, PEC. & - & Gravimetric Method \\
\hline 3 & DO & $\begin{array}{l}\text { Glass, } \\
\text { Bottles }\end{array}$ & Alkali iodide azide $\& \& \mathrm{MnSO}_{4}$ & Winkler Method with Azide Modification \\
\hline 4 & BOD & BSGB, PEC. & Refrigeration at $4^{\circ} \mathrm{C}$ & $\begin{array}{l}\text { Winkler Method with Azide Modificatio } \\
\left(\mathrm{BOD}_{5} \text { at } 20^{\circ} \mathrm{C} \text { ) }\right.\end{array}$ \\
\hline 5 & COD & BSGB, PEC. & Add $\mathrm{H}_{2} \mathrm{SO}_{4}$ refrigerate at $4^{\circ} \mathrm{C}$ & Open Reflux Method \\
\hline 6 & $\begin{array}{l}\text { Dissolved } \\
\text { Phosphate }\end{array}$ & $\begin{array}{l}\text { Glass bottle } \\
\text { rinsed withl+1 } \\
\mathrm{HNO}_{3}\end{array}$ & $\mathrm{HNO}_{3}$ or $\mathrm{H}_{2} \mathrm{SO}_{4}$ filter immediately, refrigerate & $\begin{array}{l}\text { Stannous Chloride Method by } \\
\text { Colorimeter }\end{array}$ \\
\hline 7 & Nitrate & BSGB, PEC. & Analyses as soon as possible or refrigerate & UV Spectro-photometric Method \\
\hline 8 & Ammonia & BSGB, PEC. & Add $\mathrm{H}_{2} \mathrm{SO}_{4}$ to $\mathrm{pH}<2$ refrigerate & $\begin{array}{l}\text { Nessler Reagent With Spectro- } \\
\text { photometric Method }\end{array}$ \\
\hline 9 & Heavy Metals & BSGB, PEC. & Add $\mathrm{HNO}_{3}$ to $\mathrm{pH}<2$ & Atomic Absorption Spectrometry \\
\hline
\end{tabular}

Table 2: Physico-Chemical Parameters of Ground Water Sample in Mg/Lit For Pre Monsoon Season

\begin{tabular}{|c|c|c|c|c|c|c|c|c|c|}
\hline $\begin{array}{c}\text { Name of } \\
\text { village }\end{array}$ & $\mathrm{pH}$ & $\begin{array}{c}\text { TSS } \\
\mathrm{mg} / \mathrm{lit}\end{array}$ & $\begin{array}{c}\text { TDS } \\
\text { mg/lit }\end{array}$ & $\begin{array}{c}\text { Dissolved } \\
\text { Oxygen } \\
\text { mg/lit }\end{array}$ & $\begin{array}{l}\text { COD } \\
\mathrm{mg} / \mathrm{lit}\end{array}$ & $\begin{array}{c}\text { BOD } \\
\mathrm{mg} / \mathrm{lit}\end{array}$ & $\begin{array}{c}\text { Dissolved } \\
\text { Phosphate } \\
\text { mg/lit }\end{array}$ & $\begin{array}{c}\text { Nitrate } \\
\text { as } \mathrm{NO}_{3} \\
\mathrm{mg} / \mathrm{lit}\end{array}$ & $\begin{array}{c}\text { Ammonia } \\
\mathrm{mg} / \mathrm{lit}\end{array}$ \\
\hline Aherwadi & 6.94 & 20.0 & 1560.0 & 3.7 & 24.0 & $<1.00$ & 1.23 & 1.21 & 1.68 \\
\hline Sindhkhed & 6.94 & 22.0 & 1560.0 & 4.0 & 56.0 & $<1.00$ & 1.36 & 1.23 & 1.12 \\
\hline Madre & 7.35 & 18.0 & 402.0 & 3.7 & $<4.0$ & $<1.00$ & 1.56 & 5.13 & 1.40 \\
\hline Fatatewadi & 6.92 & 15.0 & 1360.0 & 3.9 & $<4.0$ & $<1.00$ & 1.56 & 7.10 & 1.12 \\
\hline Kanabas & 7.26 & 19.0 & 612.0 & 4.0 & 24.0 & $<1.00$ & 1.21 & 3.69 & 1.68 \\
\hline Borwl & 7.42 & 13.0 & 966.0 & 3.8 & 40.0 & $<1.00$ & $<0.1$ & 6.50 & $<0.10$ \\
\hline Alegaon & 7.21 & 15.0 & 452.0 & 3.6 & 21.0 & $<1.00$ & $<0.1$ & 4.56 & 1.41 \\
\hline Tillehal & 7.85 & 16.0 & 384.0 & 3.7 & 8.0 & $<1.00$ & $<0.1$ & 10.90 & 1.96 \\
\hline Hotgi Village & 7.18 & 14.0 & 1200.0 & 3.8 & 24.0 & $<1.00$ & 1.23 & 3.56 & 1.96 \\
\hline Hanamgaon & 7.44 & 19.0 & 582.0 & 3.8 & $<4.0$ & $<1.00$ & 1.42 & 10.50 & 1.68 \\
\hline Hotgi Station & 7.42 & 23.0 & 462.0 & 3.8 & 8.0 & $<1.00$ & 0.89 & 11.80 & 1.96 \\
\hline
\end{tabular}

Table 3: Physico-Chemical Parameters of Ground Water Sample in mg/lit For Post Monsoon Season

\begin{tabular}{|c|c|c|c|c|c|c|c|c|c|}
\hline $\begin{array}{l}\text { Name of } \\
\text { village }\end{array}$ & $\mathrm{pH}$ & $\begin{array}{l}\text { TSS } \\
\mathrm{mg} / \mathrm{lit}\end{array}$ & $\begin{array}{l}\text { TDS } \\
\mathrm{mg} / \mathrm{lit}\end{array}$ & $\begin{array}{l}\text { Dissolved } \\
\text { Oxygen } \\
\text { mg/lit }\end{array}$ & $\begin{array}{l}\text { COD } \\
\mathrm{mg} / \mathrm{lit}\end{array}$ & $\begin{array}{l}\text { BOD } \\
\mathrm{mg} / \mathrm{lit}\end{array}$ & $\begin{array}{l}\text { Dissolved } \\
\text { Phosphate } \\
\text { mg/lit }\end{array}$ & $\begin{array}{l}\text { Nitrate } \\
\text { as } \mathrm{NO}_{3} \\
\mathrm{mg} / \mathrm{lit}\end{array}$ & $\begin{array}{l}\text { Ammonia } \\
\mathrm{mg} / \mathrm{lit}\end{array}$ \\
\hline Aherwadi & 7.42 & 13.0 & 252.0 & 5.0 & 12.24 & $<10.0$ & 0.03 & 4.23 & 0.28 \\
\hline Sindhkhed & 7.72 & $<10.0$ & 1483.0 & 4.2 & 32.65 & 11.0 & 0.48 & 1.56 & 0.84 \\
\hline Madre & 7.02 & $<10.0$ & 2841.0 & 6.8 & 36.73 & 13.0 & 0.63 & 4.0 & 0.84 \\
\hline Fatatewadi & 7.31 & 11.0 & 1386.0 & 6.0 & 40.82 & 13.0 & $<0.01$ & 4.25 & 1.12 \\
\hline Kanabas & 7.56 & $<10.0$ & 928.0 & 5.5 & 32.65 & 11.0 & $<0.01$ & 4.26 & 0.84 \\
\hline Borwl & 7.47 & $<10.0$ & 434.0 & 6.0 & $<10.0$ & $<10.0$ & 0.01 & 0.33 & $<0.10$ \\
\hline Alegaon & 7.90 & $<10.0$ & 1574.0 & 4.5 & 28.57 & $<10.0$ & $<0.01$ & 0.36 & 0.84 \\
\hline Tillehal & 7.87 & $<10.0$ & 350.0 & 5.2 & 12.24 & $<10.0$ & $<0.01$ & 3.58 & 0.28 \\
\hline Hotgi Village & 7.87 & $<10.0$ & 1521.0 & 6.5 & 32.65 & 11.0 & 1.08 & 0.34 & 0.84 \\
\hline Hanamgaon & 7.74 & $<10.0$ & 718.0 & 5.0 & 20.41 & $<10.0$ & $<0.01$ & 1.10 & 0.56 \\
\hline Hotgi Station & 7.41 & 11.7 & 1451.0 & 5.6 & 43.15 & 14.3 & $<0.01$ & 4.0 & 1.10 \\
\hline
\end{tabular}

\section{CONCLUSION}

The study was aimed to assess the physico-chemical characteristics of South Solapur taluka in the Solapur district. The water quality in pre and post monsoon season was analyzed to know the ground water contamination due to decreasing rainfall in the area. The analytical results of ground water concluded that the deficient rain fall reduces the quantity of water As per Table-2 and Table-3, the water quality revealed that $\mathrm{pH}$ is in between 7.02-7.90 in pre monsoon is higher than post monsoon. TSS \& TDS is 13-22 $\mathrm{mg} / \mathrm{l}$ and 384-1560 mg/l in post monsoon respectively.

The Dissolved oxygen concentration was noticed at 4.2-6.8 $\mathrm{mg} / \mathrm{l}$ in pre monsoon which is more than post monsoon. In post monsoon season COD was <4.0.-56mg/1, BOD <10.0-14.3 
$\mathrm{mg} / \mathrm{l}$ and dissolved phosphate, nitrate and ammonia were $<0.1-1.56 \mathrm{mg} / \mathrm{l}$, Nitrate $1.21-10.90 \mathrm{mg} / \mathrm{l}$ and $<0.10-1.96 \mathrm{mg} / \mathrm{l}$ respectively which was much more concentrated than in pre-monsoon season. The water quality parameters revealed that the results in the pre-monsoon and post-monsoon shows reverse deviation and more concentrated in the posmonsoon season than pre-monsoon season.

\section{ACKNOWLEDGEMENTS}

Authors wish to express their sincere gratitude to the management of the Solapur Thermal Power Station.

\section{REFERENCES}

APHA, (1995) Standard methods for examination of water and waste water, 19th edn. American Public health association, Washington, DC.

Bureau of Indian Standards (BIS), (2012) IS 10500:2012, Edition 2.1

BIT, (1995) Drinking water specification (First revision), IS, 10500.

WHO (World Health Organization) (1993) Guidelines for drinking water quality. Second Edition, Vol. 1, 188.

Sharma Aruna et al., Khan, T.I. (2009) Organochlorine pesticides in irrigation water Jaipur city (India) Central Public Health and

Environmental Engineering organization. Manual on water supply and Treatment, Ministry of works and housing New-Delhi.

Hiremath, S.C., Yadawe, M.S., Pujeri, U.S., Hiremath, D.M., Pujar, A.S. (2011) Physicochemical analysis of ground water in municipal area of Bijapur (Karnataka). Curr. World Environ. 6: 265269. https://doi.org/10.12944/cwe.6.2.09

Obire, O., Ogan, A., Okigbo, R.N. (2008) Impact of fertilizer plant effluent on water quality. Int. J. Environ. Sci. Technol., 5(1): 107118. https://doi.org/10.1007/bf03326003

Patil, P.N., Sawant, D.V., Deshmukh, R.N. (2012) Physicochemical parameters for testing of water A review. Int. J. Environ. Sci., 3(3): 11941207.

Singh, V. \& Chandel, C.P.S. (2004). The potability of groundwater in terms of Water Quality Index (WQ1) of Jaipur city. Cheml Environ. Res., 13(3\&4): 307314.

Sorg, I.J. , (1998) Treatment technology to meet the primary drinking water regulation for inorganics (Part-1) (q). J. Am. Wat. Works Astt., 70(2): 105 112. https://doi.org/10.1002/j.1551-8833.1978.tb06881.x

Tiwari, R.K. et al., Goel, P.K. (1986) Chemical and Biological method for water pollution studies, Environmental Publication, Karad, India.

Sawyer G.N., Carthy Mc D.L (1967) Chemistry of sanitary Engineers, $2^{\text {nd }}$ Ed. McGraw Hill, New York, 1(2): 518

0 2019| Published by Plantae Scientia 